\title{
Zeaxanthin Inhibits Hypoxia-Induced VEGF Secretion by RPE Cells through Decreased Protein Levels of Hypoxia-Inducible Factors-1 $\alpha$
}

\author{
Richard Rosen, ${ }^{1,2}$ Tommaso Vagaggini, ${ }^{3}$ Yueqin Chen, ${ }^{3}$ and Dan-Ning $\mathrm{Hu}^{1,2,3,4}$ \\ ${ }^{1}$ Department of Ophthalmology, The New York Eye and Ear Infirmary of Mount Sinai Health System, \\ 310 E. 14th Street, New York, NY 10003, USA \\ ${ }^{2}$ Icahn School of Medicine at Mount Sinai, New York, NY 10029, USA \\ ${ }^{3}$ Tissue Culture Center, The New York Eye and Ear Infirmary of Mount Sinai Health System, \\ 310 E. 14th Street, New York, NY 10003, USA \\ ${ }^{4}$ Department of Pathology, The New York Eye and Ear Infirmary of Mount Sinai Health System, \\ 310 E. 14th Street, New York, NY 10003, USA
}

Correspondence should be addressed to Dan-Ning Hu; hu2095@yahoo.com

Received 3 September 2014; Accepted 15 December 2014

Academic Editor: Takashi Saku

Copyright (C) 2015 Richard Rosen et al. This is an open access article distributed under the Creative Commons Attribution License, which permits unrestricted use, distribution, and reproduction in any medium, provided the original work is properly cited.

\begin{abstract}
Hypoxia is the most important stimulus leading to upregulation of VEGF in the retina and this is caused by accumulation of hypoxia-inducible factors- $1 \alpha$ (HIF- $1 \alpha$ ) protein. The effects of zeaxanthin, a natural phytochemical, on the VEGF and HIF-1 $\alpha$ expression in the primary culture of human retinal pigment epithelial (RPE) cells were studied. An in vitro RPE cell hypoxia model was established by placing cells under $1 \%$ oxygen pressure or by adding cobalt chloride $\left(\mathrm{CoCl}_{2}\right)$ to the culture medium. RPE cells and conditioned media were collected from cultures treated with and without zeaxanthin under normoxic and hypoxic conditions. VEGF and HIF- $1 \alpha$ protein and RNA levels were measured by ELISA kits and RT-PCR, respectively. Hypoxia caused a significant increase of VEGF expression and accumulation of HIF- $1 \alpha$ in RPE cells. Zeaxanthin at 50-150 $\mu \mathrm{M}$ significantly inhibited the expression of VEGF and accumulation of HIF-1 $\alpha$ protein caused by hypoxia but did not affect expression of VEGF and HIF-1 $\alpha$ under normoxic conditions. This is the first report on the effect of zeaxanthin on VEGF and HIF-1 $\alpha$ levels in cultured RPE cells and suggests that zeaxanthin may have potential value in the prevention and treatment of various retinal diseases associated with vascular leakage and neovascularization.
\end{abstract}

\section{Introduction}

Vascular endothelial growth factor (VEGF) is a growth factor that stimulates the proliferation and migration of vascular endothelial cells and increases vascular permeability $[1,2]$. VEGF is the most powerful angiogenesis promoter and plays a significant role in the pathogenesis of ocular neovascularization diseases, such as diabetic retinopathy and exudative type of age-related macular degeneration (AMD) [3-9].

The most important pathophysiological stimulus leading to high levels of VEGF expression in the retina is hypoxia [3, $4,7,9]$. Hypoxia causes the increase of VEGF by the accumulation of a transcription factor, hypoxia-inducible factor- $1 \alpha$ $(H I F-1 \alpha)$, which promotes the production and secretion of
VEGF by various cells including retinal pigment epithelial (RPE) cells [10-26]. Hypoxia is closely related to the development of neovascularization in the eye. Any drug that inhibits this process may have a therapeutic effect on various retinal diseases related to neovascularization.

Zeaxanthin, a natural phytochemical, is a carotenoid pigment of the xanthophyll subclass with a chemical formula $\mathrm{C}_{40} \mathrm{H}_{56} \mathrm{O}_{2}$. Zeaxanthin is present in various tissues and, in particular, is highly concentrated in the central retina (macula) of the eye [27-32]. Various observational and interventional studies have indicated that zeaxanthin might help reduce the risk of age-related macular degeneration (AMD) [33-41]. In vitro studies have demonstrated that zeaxanthin protected RPE cells and various retinal neurons against 
oxidative stress [42-46]. Zeaxanthin is an antioxidant and also works as a filter protecting the macula from the blue light [42-47]. Recent studies have shown that in addition to traditional mechanisms, zeaxanthin can influence the viability and function of cells through various signal pathways or transcription factors $[46,48]$.

It has been reported that zeaxanthin decreased the upregulation of VEGF in the retina in diabetic rats and in apoliprotein deficient mice $[49,50]$. Lutein, a carotenoid with similar structure and function as zeaxanthin, decreases high VEGF expression of human RPE cells or mouse macrophages following tumor necrosis factor- $\alpha$ and lipopolysaccharide stimulations, respectively [51]. To the best of our knowledge, the effects of zeaxanthin on VEGF expression in cultured RPE cells have not been previously reported.

The purposes of the present study were to investigate the effects of zeaxanthin on the expression and secretion of VEGF by RPE cells under normoxic and hypoxic conditions and to explore the mechanism of action by measurement of HIF- $1 \alpha$ levels in RPE cells under normoxia and hypoxia, with and without zeaxanthin.

\section{Materials and Methods}

2.1. Cell Culture. A culture of primary human RPE cells was isolated from a donor eye (56 years old) and cultured as previously described $[52,53]$. Cells were cultured in Dulbecco's modified Eagle's medium (DMEM, GIBCO, Carlsbad, CA) supplemented with $10 \%$ fetal bovine serum (FBS, GIBCO). Cells were incubated in a humidified $5 \% \mathrm{CO}_{2}$ atmosphere at $37^{\circ} \mathrm{C}$. After reaching confluence, cells were detached by trypsin-EDTA solution (GIBCO), diluted at $1: 3-1: 4$, plated for subculture, and passaged routinely at a dilution of $1: 3-1: 4$ every $5-7 \mathrm{~d}$.

Phase-contrast microscopy revealed pigmentation of RPE cells during the primary culture and the first and second subcultures. Cells displayed characteristic epithelial morphology throughout the culture period. The purity of the cell lines was demonstrated by immunocytochemical methods as previously reported. RPE cells display positive staining of cytokeratin, whereas fibroblasts and melanocytes do not [54].

\subsection{Effect of Hypoxia on Secretion of VEGF by RPE Cells. RPE} cells were seeded into 24 -well plates at a density of $1 \times 10^{5}$ cells per well. After $24 \mathrm{~h}$, the culture medium was withdrawn. The cultures were washed with PBS twice and fresh culture medium was added. In the hypoxia experiment, cells were incubated in a sealed chamber at $37^{\circ} \mathrm{C}$ for $24 \mathrm{~h}$ in a controlled environment of $1 \% \mathrm{O}_{2}$ in the presence of $5 \% \mathrm{CO}_{2}$ and $94 \% \mathrm{~N}_{2}$ by using a PROOX 100 System (BioSherix, Redfield, NT). Cells cultured under standard conditions $\left(21 \% \mathrm{O}_{2}, 5 \%\right.$ $\mathrm{CO}_{2}$, and $74 \% \mathrm{~N}_{2}$ ) served as normoxia control cultures. Conditioned medium was collected 24 hours later and centrifuged at $800 \times \mathrm{g}$ for $5 \mathrm{~min}$, and the supernatants were transferred to vials and stored at $-70^{\circ} \mathrm{C}$ until analysis. All experiments were performed in triplicate.
2.3. Effect of Chemical Hypoxia on Secretion of VEGF by RPE Cells. RPE cells were seeded into 24 -well plates as described above. Culture medium was replaced $24 \mathrm{~h}$ after seeding and cobalt chloride $\left(\mathrm{CoCl}_{2}\right)$ (Sigma, St. Louis, MO), an iron analogue, was added into the medium to mimic hypoxic conditions. The $\mathrm{CoCl}_{2}$ concentrations used in the literatures had a wide variation [55-57]. Therefore, the dose effects of $\mathrm{CoCl}_{2}$ were tested over a wide range of $\mathrm{CoCl}_{2}$ (at concentrations of 50,100,150, and $200 \mu \mathrm{M}$ ). Cells cultured without $\mathrm{CoCl}_{2}$ served as normal controls. Conditioned medium was collected $24 \mathrm{~h}$ later, centrifuged, and stored as described above. All experiments were performed in triplicate.

2.4. Effect of Zeaxanthin on Secretion of VEGF by RPE Cells under Normoxia. RPE cells were seeded into 24-well plates at a density of $1 \times 10^{5}$ cells per well. After $24 \mathrm{~h}$, the culture medium was withdrawn. The cultures were washed with PBS twice and fresh culture medium was added. Zeaxanthin (ZeaVision LLC, Chesterfield, MO) $6.82 \mathrm{mg}$ was dissolved in $200 \mu \mathrm{L}$ DMSO to make a stock solution of $60 \mathrm{mM}$. Tested cells were treated by different concentrations of zeaxanthin. The cells in the control group were cultured in medium containing the same levels of DMSO as in the zeaxanthin solution. A separate investigation of the effects of the highest DMSO levels $(1: 400)$ used in this experiment did not show significant differences in the cell viability between the cells with and without DMSO (data not shown). Conditioned medium was collected $24 \mathrm{~h}$ later, centrifuged, and stored as described above. All experiments were performed in triplicate.

\subsection{Effect of Zeaxanthin on the Secretion of VEGF by RPE Cells} under Hypoxia. RPE cells were seeded into 24-well plates and the culture medium was replaced $24 \mathrm{~h}$ later as described above. Zeaxanthin was added to the medium at different concentrations. One hour later, cells were incubated in a controlled environment of $1 \% \mathrm{O}_{2}$ as described above. Cells cultured under hypoxia without zeaxanthin were used as positive controls. Cells cultured under normoxic conditions were used as negative controls. Conditioned medium was collected $24 \mathrm{~h}$ later, centrifuged, and stored as described above. All experiments were performed in triplicate.

2.6. Effect of Zeaxanthin on the Secretion of VEGF by RPE Cells under Chemical Hypoxia. RPE cells were seeded into 24-well plates and the culture medium was replaced $24 \mathrm{~h}$ later as described above. $\mathrm{CoCl}_{2}$ was added to mimic hypoxic conditions. Cells cultured with $\mathrm{CoCl}_{2}$ but without zeaxanthin were used as positive controls. Cells cultured without $\mathrm{CoCl}_{2}$ were used as negative controls. Conditioned medium was collected $24 \mathrm{~h}$ later, centrifuged, and stored as described above. All experiments were performed in triplicate.

\subsection{Effects of Hypoxia and Zeaxanthin on Cell Viability of} RPE Cells. RPE cells were seeded into 96-well plates at a density of $5 \times 10^{3}$ cells per well. Cells were incubated under normoxic or hypoxic conditions $\left(1 \% \mathrm{O}_{2}\right)$ or with added $\mathrm{CoCl}_{2}$ at various concentrations. In the study of effects of zeaxanthin on the cell viability, zeaxanthin at $1,50,100$, and $150 \mu \mathrm{M}$ was 
added into the culture medium under normoxic condition. After $24 \mathrm{~h}$, MTT solution $(1 \mathrm{mg} / \mathrm{mL}, 50 \mu \mathrm{L})$ was added. After $4 \mathrm{~h}$ incubation, the medium and MTT were aspirated and $100 \mu \mathrm{L}$ of DMSO was added. Optical density of the plates was determined with a microplate reader (Multiskan MCC/340, Fisher Scientific, Pittsburgh, PA, USA) at $540 \mathrm{~nm}$ [58]. The optical density in control (normoxic) cells was taken as $100 \%$ viability. All tests were performed in three independent experiments.

2.8. Measurement of VEGF Levels. The amount of VEGF protein in the conditioned media was determined using the human VEGF Quantikine ELISA kits (R\&D Systems, Minneapolis, MN, USA) according to the manufacturer's instructions. Optical density was read using a microplate reader at $450 \mathrm{~nm}$ and corrected with $540 \mathrm{~nm}$. The amount of VEGF $(\mathrm{pg} / \mathrm{mL})$ was calculated from a standard curve. The sensitivity of the VEGF kits was $5.0 \mathrm{pg} / \mathrm{mL}$.

2.9. RNA Isolation and RT-PCR. RPE cells were seeded into 6 -well plates and the culture medium was replaced $24 \mathrm{~h}$ later as described above. Zeaxanthin was added to the medium at $150 \mu \mathrm{M}$. One hour later, cells were incubated in a controlled environment of $1 \% \mathrm{O}_{2}$ as described above. Cells cultured with $1 \% \mathrm{O}_{2}$ but without zeaxanthin were used as positive controls. Cells cultured under normoxic conditions were used as negative controls. After $24 \mathrm{~h}$, the culture medium was withdrawn, the cultures were washed with cold PBS, and cells were harvested. After microcentrifuging at $800 \times \mathrm{g}$ for 5 min at $4^{\circ} \mathrm{C}$, cell pellets were collected for mRNA extraction. Total RNA was isolated with the RNeasy mini kit (QIAGEN, Valencia, CA), according to the manufacturer's instructions. The SuperScript first-strand synthesis system for RTPCR kit (Invitrogen, Camarillo, CA) was used to perform cDNA synthesis. The PCR primers for glyceraldehyde-3phosphate dehydrogenase (GAPDH) were TGAACTGAAAGCTCTCCACC and CTGATGTACCAGTTGGGGAA. VEGF primers were AGGGCAGAACATCACGAAGT and ACGGTCTCGATTGGATGGCA. HIF-1 primers were GAACGTCGAAAAGAAAAGTCTCG and CCTTATCAAGATGCGAACTCACA. All primers were obtained from Invitrogen. The first-strand cDNAs were synthesized from $1.0 \mu \mathrm{g}$ of total RNA at $50^{\circ} \mathrm{C}$ for $50 \mathrm{~min}$. PCR amplification was conducted in a GeneAmp PCR system 9700 (Applied Biosystems, Foster City, CA) using the following parameters: first denaturation at $94^{\circ} \mathrm{C}$ for $5 \mathrm{~min}$ followed by 35 cycles of reactions of denaturation at $94^{\circ} \mathrm{C}$ for $30 \mathrm{~s}$, annealing at $58^{\circ} \mathrm{C}$ for $45 \mathrm{~s}$, and extension at $72^{\circ} \mathrm{C}$ for $45 \mathrm{~s}$ and last extension for $5 \mathrm{~min}$ at $72^{\circ} \mathrm{C}$. After amplification, samples were run on a $1 \%$ agarose gel (Invitrogen) in TBE (0.01 M Tris-borate) and 0.001 M EDTA (Invitrogen) containing $2.0 \mu \mathrm{g} / \mathrm{mL}$ ethidium bromide (Invitrogen). Bands were visualized and photographed on a UV transilluminator (ChemiDoc XRS System, Bio-Rad, Hercules, CA, USA).

2.10. Effect of Hypoxia and Zeaxanthin on HIF-1 $\alpha$ Protein Levels in RPE Cells. RPE cells were seeded into $6 \mathrm{~cm}$ culture dishes at a density of $2 \times 10^{6}$ cells per well. After $24 \mathrm{~h}$, the culture medium was replaced as described above. One hour later, cells were incubated in a controlled environment of $1 \% \mathrm{O}_{2}$ or with added $\mathrm{CoCl}_{2}$ at various concentrations. Cells cultured under normoxic condition and without $\mathrm{CoCl}_{2}$ were served as normal controls. After $24 \mathrm{~h}$, cells were collected as described above and treated with cell lysis buffer (SIGMA) and centrifuged at $2000 \times \mathrm{g}$ for $5 \mathrm{~min}$ and the supernatant was collected. Protein levels were measured with BCA Protein Assay Kit (Thermo Scientific, Rockfield, IL). In zeaxanthin studies, zeaxanthin at different concentrations was added to the culture medium; $1 \mathrm{~h}$ later, cells were incubated under $1 \% \mathrm{O}_{2}$ or added with $\mathrm{CoCl}_{2}$ at $150 \mu \mathrm{M}$. Cells cultured under normoxic condition and without $\mathrm{CoCl}_{2}$ served as negative controls. Cells cultured under $\mathrm{O}_{2}$ or with $\mathrm{CoCl}_{2}$ but without zeaxanthin served as positive controls.

2.11. Measurement of HIF-1 $\alpha$ Levels in the Cell Extracts. The amount of HIF- $1 \alpha$ protein in the cell extracts was determined using the Human/Mouse Intracellular HIF-1 $\alpha$ DuoSet IC ELISA kits (R\&D Systems, Minneapolis, MN, USA) according to the manufacturer's instructions. Optical density was read by using a microplate reader at $450 \mathrm{~nm}$ and corrected with $540 \mathrm{~nm}$. The amounts of HIF- $1 \alpha(\mathrm{pg} / \mathrm{mL})$ were calculated from a standard curve and expressed as $\mathrm{pg} / \mathrm{mg}$ protein.

2.12. Statistical Analysis. Statistical significances of the difference of means throughout this study were calculated using the ANOVA one-way test for comparing data from more than two groups and Student's $t$-test for comparing data between two groups. A difference at $P<0.05$ was considered to be statistically significant.

\section{Results}

3.1. Effects of Hypoxia and Zeaxanthin on Cell Viability of RPE Cells. RPE cells cultured at $1 \% \mathrm{O}_{2}$ or with $\mathrm{CoCl}_{2}$ at $50-$ $200 \mu \mathrm{M}$ did not significantly affect the cell viability $(P>$ $0.05)$. Zeaxanthin at $50-150 \mu \mathrm{M}$ also did not significantly affect RPE cell viability $(P>0.05)$ (Figure 1$)$.

3.2. Secretion of VEGF by RPE Cells under Normoxia and Hypoxia. RPE cells had a relatively high constitutive secretion of VEGF. VEGF levels in conditioned culture medium of RPE cells cultured under normoxia were $451 \pm 50.8 \mathrm{pg} / \mathrm{mL}$ (mean $\pm \mathrm{SD})$. Cells cultured under hypoxia $\left(1 \% \mathrm{O}_{2}\right)$ significantly increased the VEGF levels in the culture medium 2.36-fold over cells cultured under normoxia $(P<0.05)$ (Figure 2(a)). $\mathrm{CoCl}_{2}$ at concentrations from 50 to $200 \mu \mathrm{M}$ caused a dose-dependent increase of VEGF levels (all $\mathrm{CoCl}_{2}$ treated cultures compared to the control, $P<0.05 ; 50 \mu \mathrm{M}$ compared to $100 \mu \mathrm{M}$ and $100 \mu \mathrm{M}$ compared to $150 \mu \mathrm{M}, P<$ $0.05 ; 150 \mu \mathrm{M}$ compared with $200 \mu \mathrm{M}, P>0.05$ ) (Figure 2(b)). $\mathrm{CoCl}_{2}$ stimulated effects on secretion of VEGF reached the peak at $150 \mu \mathrm{M}$, which induced a 2.97-fold increase in secretion of VEGF as compared with cells cultured under normoxia. Therefore, $150 \mu \mathrm{M} \mathrm{CoCl}_{2}$ was selected as the concentration of $\mathrm{CoCl}_{2}$ used in the following experiments. 


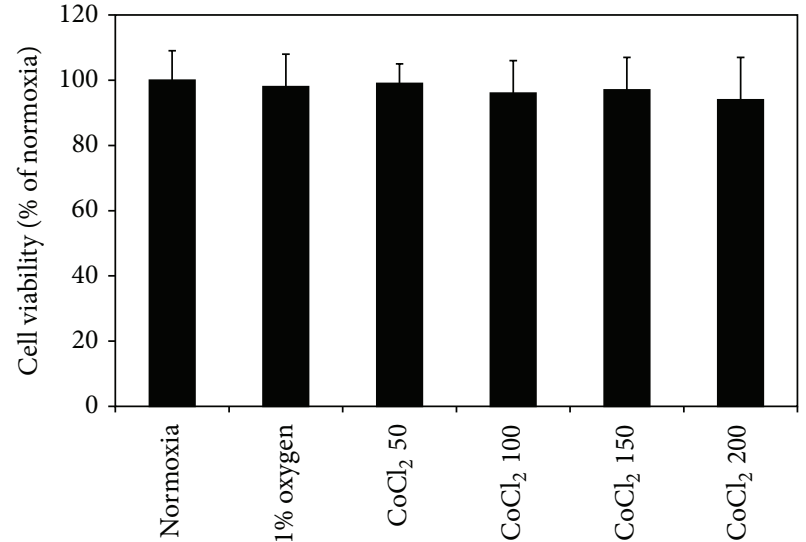

(a)

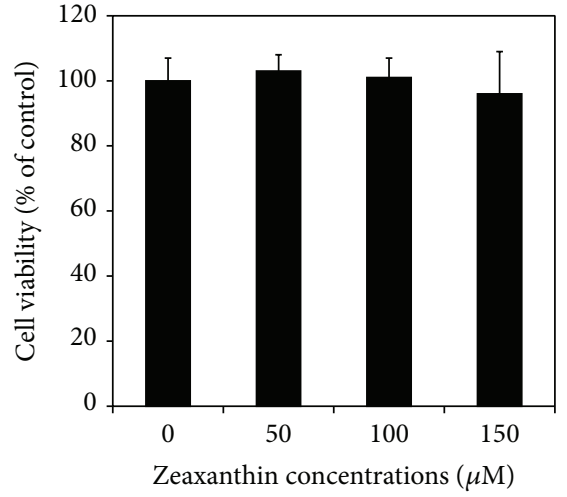

(b)

FIGURE 1: Effects of hypoxia and zeaxanthin on cell viability of retinal pigment epithelial (RPE) cells. RPE cells were seeded into 96-well plates at a density of $5 \times 10^{3}$ cells per well. Cells were incubated under normoxic or hypoxic conditions $\left(1 \% \mathrm{O}_{2}\right)$ or cultured with $\mathrm{CoCl}_{2}$ at 50,100 , 150 , and $200 \mu \mathrm{M}$ (a). Zeaxanthin at 1,50,100, and $150 \mu \mathrm{M}$ was added into the culture medium under normoxic condition (b). After $24 \mathrm{~h}$, cell viability was determined by MTT assay (see Section 2). Hypoxia and zeaxanthin at test concentrations did not affect the cell viability $(P>0.05)$. Data are expressed as the percentage of optical readings in normoxia (mean $\pm \mathrm{SD}, n=3)$.

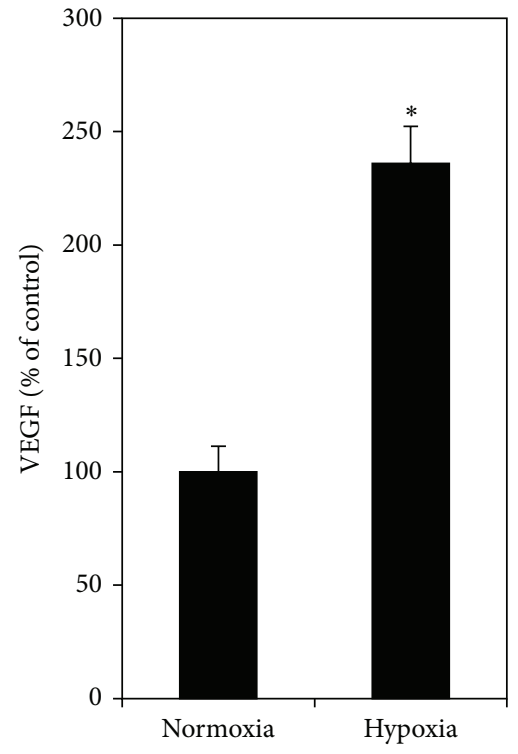

(a)

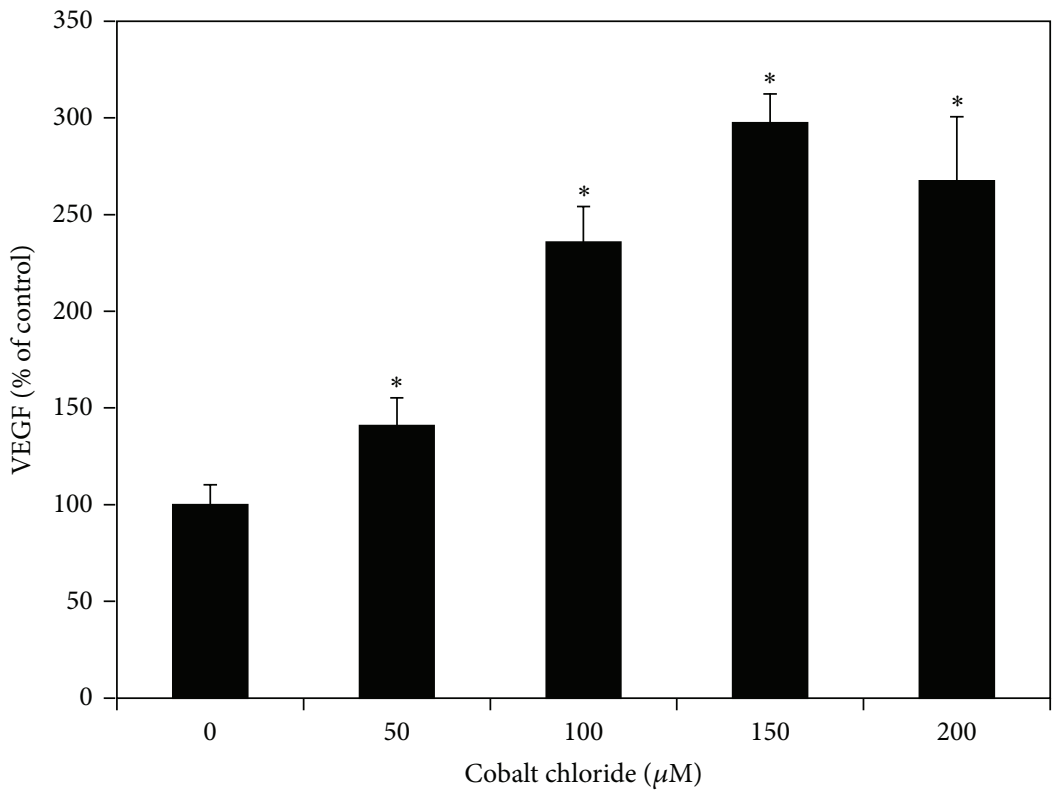

(b)

Figure 2: Effects of hypoxia on secretion of VEGF by RPE cells. RPE cells were seeded into 24 -well plates at a density of $1 \times 10^{5}$ cells per well. After $24 \mathrm{~h}$, cells were incubated in a sealed chamber in a controlled environment of $1 \% \mathrm{O}_{2}$ (a) or cultured with CoCl $\mathrm{C}_{2}$ at $50,100,150$, and $200 \mu \mathrm{M}$ concentrations (b). Cells cultured under normal oxygen pressure $\left(21 \% \mathrm{O}_{2}, 5 \% \mathrm{CO}_{2}\right.$, and $\left.74 \% \mathrm{~N}_{2}\right)$ were served as the control. Conditioned medium was collected $24 \mathrm{~h}$ later; VEGF levels were measured by VEGF ELISA kits and expressed as percentages of the control (mean $\pm \mathrm{SD}, n=3$ ). Hypoxia significantly increased VEGF secretion by RPE cells. ${ }^{*} P<0.05$, compared with the controls.

3.3. Effect of Zeaxanthin on Secretion of VEGF by RPE Cells under Normoxia and Hypoxia. Under normoxic condition, zeaxanthin at $50-100 \mu \mathrm{M}$ did not influence the secretion of VEGF by RPE cells ( $P>0.05$ ) (Figure 3 ). Cells cultured with zeaxanthin at $150 \mu \mathrm{M}$ showed a slight decrease of VEGF secretion as compared with cells not cultured with zeaxanthin; however, this difference was not statistically significant $(P>0.05)$.
Under hypoxic condition $\left(1 \% \mathrm{O}_{2}\right)$, zeaxanthin at $50-$ $150 \mu \mathrm{M}$ dose-dependently decreased the secretion of VEGF as compared with cells cultured under hypoxia but without zeaxanthin (compared to hypoxia without zeaxanthin, $P>$ 0.05 at $50 \mu \mathrm{M}$ and $P<0.05$ at $100-150 \mu \mathrm{M})(50 \mu \mathrm{M}$ compared to $100 \mu \mathrm{M}, P<0.05 ; 100 \mu \mathrm{M}$ compared to $150 \mu \mathrm{M}, P>$ 0.05 ) (Figure $4(\mathrm{a})$ ). Secretion of VEGF in cells cultured with zeaxanthin at $150 \mu \mathrm{M}$ decreased to levels near those of cells 


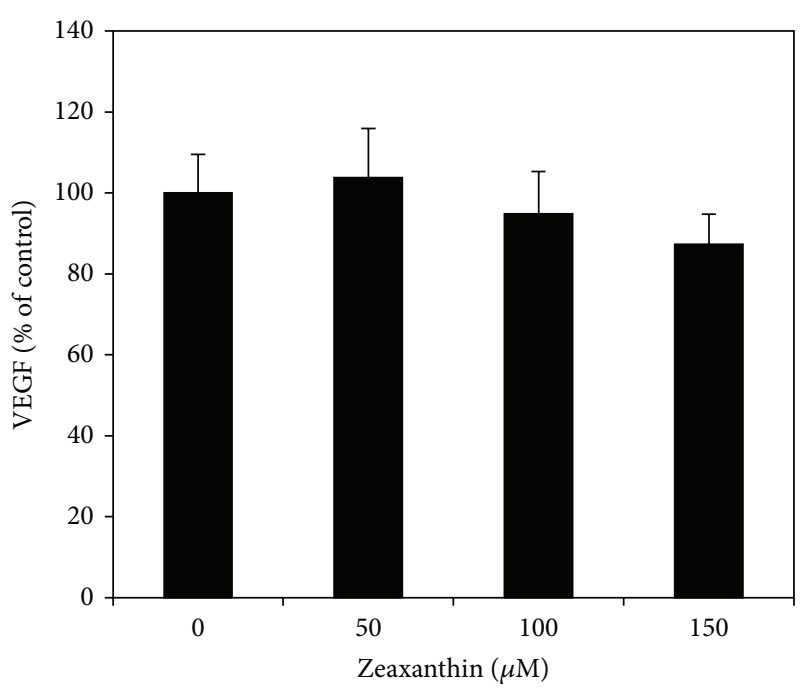

FIGURE 3: Effect of zeaxanthin on secretion of VEGF by RPE cells under normoxia. RPE cells were seeded into 24 -well plates at a density of $1 \times 10^{5}$ cells per well. After $24 \mathrm{~h}$, zeaxanthin at 50,100 , and $150 \mu \mathrm{M}$ was added. Conditioned medium was collected $24 \mathrm{~h}$ later; VEGF levels were measured by VEGF ELISA kits and expressed as percentages of the control (mean $\pm \mathrm{SD}, n=3$ ). Zeaxanthin did not significantly affect the secretion of VEGF in cells cultured under normoxia $(P>0.05)$.

cultured under normoxia $(P>0.05)$, indicating that zeaxanthin at $150 \mu \mathrm{M}$ completely blocked hypoxia-induced secretion of VEGF by RPE cells.

In the chemical hypoxic condition $\left.(150 \mu \mathrm{M} \mathrm{CoCl})_{2}\right)$, zeaxanthin at $50-150 \mu \mathrm{M}$ also dose-dependently decreased the secretion of VEGF as compared to cells cultured under chemical hypoxia but without zeaxanthin $(P<0.05$ at all concentrations of zeaxanthin) (50 $\mu \mathrm{M}$ compared to $100 \mu \mathrm{M}$ and $100 \mu \mathrm{M}$ compared to $150 \mu \mathrm{M}, P<0.05$ ) (Figure 4(b)). Zeaxanthin at the highest tested concentrations also completely blocked $\mathrm{CoCl}_{2}$-induced secretion of VEGF by RPE cells $(P>0.05$, as compared with cells cultured without zeaxanthin).

3.4. Effects of Hypoxia and Zeaxanthin on Expression of VEGF $m R N A$. Expression of VEGF mRNA in RPE cells increased significantly in cells cultured with $1 \% \mathrm{O}_{2}$ for $24 \mathrm{~h}(P<$ $0.05)$ (Figure 5). Adding of zeaxanthin at $150 \mu \mathrm{M}$ significantly decreased the expression of VEGF mRNA $(P<0.05)$ (Figure 5), indicating that zeaxanthin blocked hypoxiainduced expression of VEGF mRNA.

3.5. Effects of Hypoxia on Intracellular HIF-1 $\alpha$ Protein Levels in RPE Cells. RPE cells cultured under hypoxia $\left(1 \% \mathrm{O}_{2}\right)$ produced significantly increased levels of HIF- $1 \alpha$ protein to 1.92 -fold of cells cultured under normoxia $(P<0.05)$ (Figure 6(a)). $\mathrm{CoCl}_{2}$ at all concentrations from 50 to $200 \mu \mathrm{M}$ caused a dose-dependent increase of HIF- $1 \alpha$ protein levels in RPE cells $(P<0.05)$ (all the $\mathrm{CoCl}_{2}$ treated group at different dosages compared to the next group, $P<0.05$ ) (Figure 6(b)). $\mathrm{CoCl}_{2}$ stimulated effects on HIF-1 $\alpha$ levels reached the peak at
$150 \mu \mathrm{M}$, which induced a 2.39-fold increase in HIF- $1 \alpha$ levels as compared with cells cultured without $\mathrm{CoCl}_{2}$. Therefore, $150 \mu \mathrm{M} \mathrm{CoCl}$ was selected as the concentration of $\mathrm{CoCl}_{2}$ used in the following experiments.

3.6. Effects of Zeaxanthin on Intracellular HIF-1 $\alpha$ Protein Levels in RPE Cells. In cells cultured with $1 \% \mathrm{O}_{2}$, zeaxanthin at $50-150 \mu \mathrm{M}$ caused a dose-dependent decrease of HIF$1 \alpha$ levels as compared with cells cultured under $1 \% \mathrm{O}_{2}$ but without zeaxanthin $(P<0.05$ at all concentrations of zeaxanthin) $(50 \mu \mathrm{M}$ compared to $100 \mu \mathrm{M}, P<0.05 ; 100 \mu \mathrm{M}$ compared to $150 \mu \mathrm{M}, P>0.05$ ) (Figure 7(a)). HIF-1 $\alpha$ levels in cells cultured with $1 \% \mathrm{O}_{2}$ and zeaxanthin at 100-150 $\mu \mathrm{M}$ showed no difference from cells cultured under normoxia $(P>0.05)$, indicating that zeaxanthin at $100-150 \mu \mathrm{M}$ could completely block hypoxia-induced intracellular accumulation of HIF- $1 \alpha$ protein.

In cells cultured with $\mathrm{CoCl}_{2}$, zeaxanthin at $50-150 \mu \mathrm{M}$ also caused a dose-dependent decrease of HIF-1 $\alpha(P<$ 0.05 at all concentrations of zeaxanthin compared with cells cultured with $\mathrm{CoCl}_{2}$ but no zeaxanthin) (50 $\mu \mathrm{M}$ compared to $100 \mu \mathrm{M}, P<0.05 ; 100 \mu \mathrm{M}$ compared to $150 \mu \mathrm{M}, P>0.05$ ) (Figure 7(b)). Zeaxanthin at 100-150 $\mu \mathrm{M}$ completely blocked $\mathrm{CoCl}_{2}$-induced accumulation of HIF-1 $\alpha$ protein $(P>0.05$, as compared with cells cultured without $\mathrm{CoCl}_{2}$ ).

3.7. Effects of Hypoxia and Zeaxanthin on Expression of HIF-1 $\alpha$ $m R N A$. Cells cultured under $1 \% \mathrm{O}_{2}$ with and without zeaxanthin did not show any significant effect on the expression of HIF-1 $\alpha$ mRNA $(P>0.05)$ (Figure 8). This indicates that both hypoxia and zeaxanthin have no effect on the expression of HIF-1 $\alpha$. Their effects on the HIF-1 $\alpha$ protein levels are mainly via the stabilization and accumulation process of HIF-1 $\alpha$ protein. This is consistent with previous reports $[17,18]$.

\section{Discussion}

In vivo and in vitro studies have indicated that the most important pathophysiological stimulus leading to high expression of VEGF in the retina is hypoxia $[3,4,7,9]$. Hypoxia causes the increase of VEGF by RPE cells mainly through the stabilization of HIF-1 $\alpha$ protein [17-22].

HIF-1 is a transcription factor for cellular and tissue adaptation to low oxygen tension and is the most important factor promoting angiogenesis via upregulation of VEGF under hypoxia [23-26]. HIF-1 is a heterodimeric factor consisting of an inducible oxygen-sensitive alpha subunit (HIF- $1 \alpha$ ) and a constitutive oxygen-insensitive beta subunit (HIF$1 \beta$ /ARNT). The expression of HIF- $1 \beta$ is not affected by changes of oxygen pressure. Cells continuously synthesize and degrade HIF- $1 \alpha$ protein. The protein level of HIF- $1 \alpha$ is tightly regulated by cellular oxygen concentration [23-26]. Under normoxic conditions, HIF- $\alpha$ subunits have a very short half-life; the proline residues in the oxygen-dependent degradation domain of HIF- $1 \alpha$ are hydroxylated by prolyl hydroxylase. Subsequently, the hydroxylated HIF- $1 \alpha$ is recognized by the Von Hippel-Lindau tumor suppressor protein, leading to ubiquitination and degradation of HIF- $1 \alpha$ 


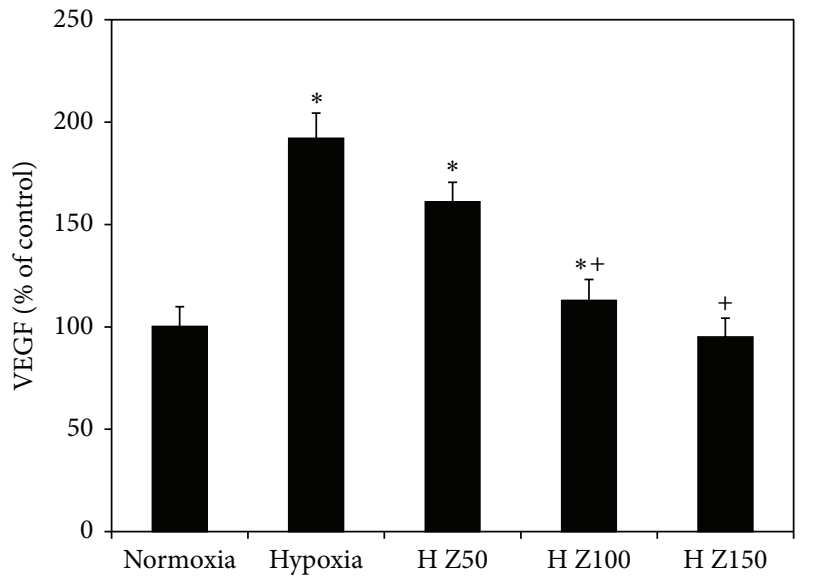

(a)

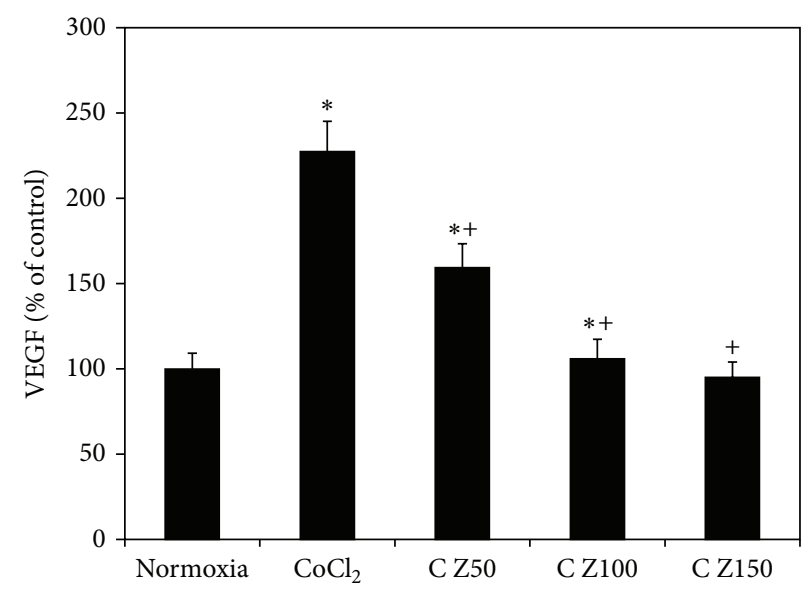

(b)

FIGURE 4: Effects of zeaxanthin on secretion of VEGF by RPE cells under hypoxia. RPE cells were seeded into 24-well plates at a density of $1 \times 10^{5}$ cells per well. After $24 \mathrm{~h}$, zeaxanthin was added at 50,100, and $150 \mu \mathrm{M}$ concentrations. One hour later, cells were incubated under $1 \% \mathrm{O}_{2}$ (a) or cultured with $\mathrm{CoCl}_{2}$ at $150 \mu \mathrm{M}$ (b). Cells cultured under normoxia and without zeaxanthin were served as negative control. Cells cultured under hypoxia and without zeaxanthin were served as positive control. Conditioned medium was collected 24 hours later; VEGF levels were measured by VEGF ELISA kits and expressed as percentages of the negative control (mean $\pm \mathrm{SD}, n=3$ ). Zeaxanthin significantly inhibited hypoxia-induced secretion of VEGF. ${ }^{*} P<0.05$, compared with the negative controls. ${ }^{+} P<0.05$, compared with the positive controls.

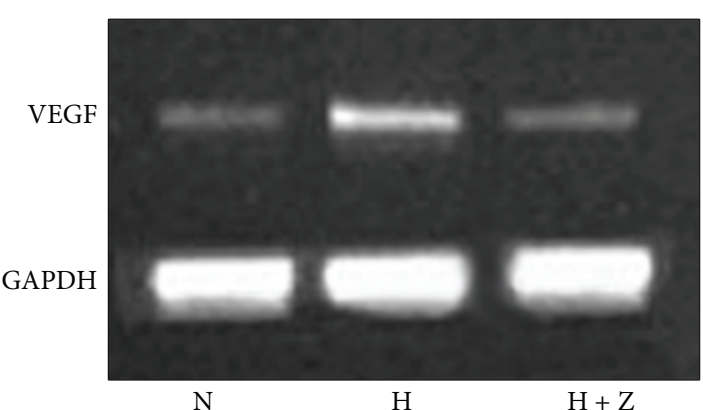

(a)

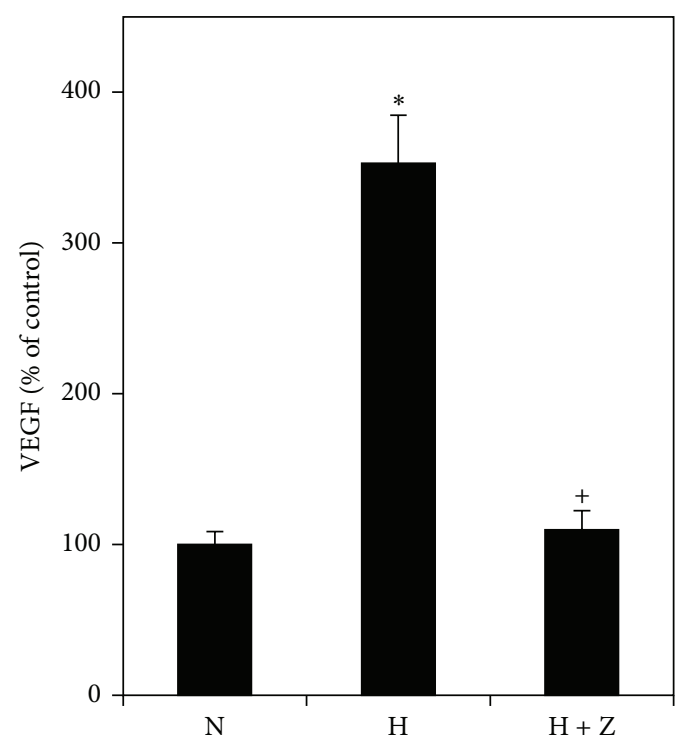

(b)

FIGURE 5: Effects of hypoxia and zeaxanthin on VEGF mRNA expression of RPE cells. (a) Representative RT-PCR profiles from three experiments. Cells were cultured under hypoxia $(1 \%$ oxygen) with $(\mathrm{H}+\mathrm{Z})$ and without zeaxanthin $(\mathrm{H})$. Cells cultured under normal oxygen condition were used as the control $(\mathrm{N})$. Cells were collected 24 hours later, mRNA was extracted, and RT-PCR analysis was performed as described in Section 2. GAPDH was used as an internal loading control. (b) Quantitative analysis showed that the expression of VEGF mRNA (mean $\pm \mathrm{SD}, n=3$ ) by cells exposed to hypoxia (1\% oxygen) was significantly increased $(\mathrm{H})$ and zeaxanthin significantly inhibited hypoxiainduced expression of $\operatorname{VEGF}(\mathrm{H}+\mathrm{Z}) .{ }^{*} \mathrm{P}<0.05$, compared with the controls.

and thereby abolishing HIF-1 $\alpha$ protein accumulation. Under hypoxia, the hydroxylation of HIF- $1 \alpha$ is impaired, which enhances stabilization and accumulation of HIF- $1 \alpha$ protein. Upon HIF-1 $\alpha$ protein accumulation, it translocates to the nucleus, stimulates expression of VEGF gene, and leads to angiogenesis [23-26].
In this in vitro study, the hypoxic condition was induced by changing the oxygen pressure in the incubator or by adding $\mathrm{CoCl}_{2}[10-22,55-57]$. Under normoxia, HIF- $1 \alpha$ is degraded by the hydroxylases. The ferrous ion bound at the active sites is essential for the activity of hydroxylases. Cobalt displaces the single free ferrous at the active site and thus 


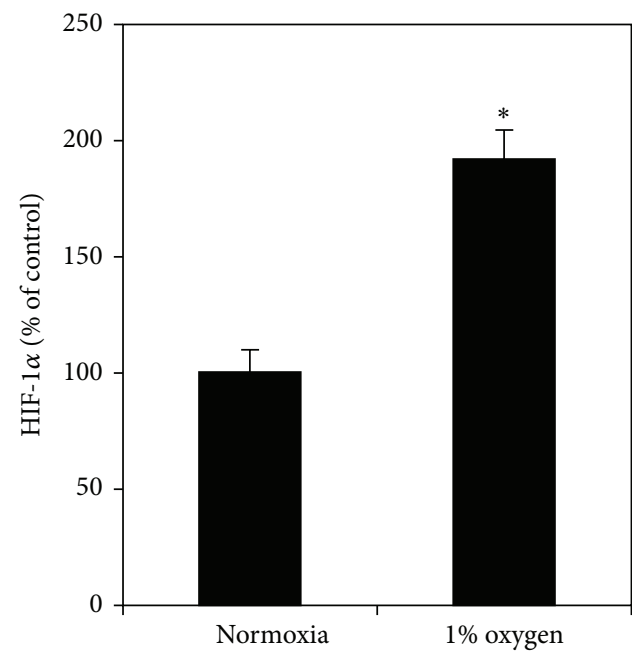

(a)

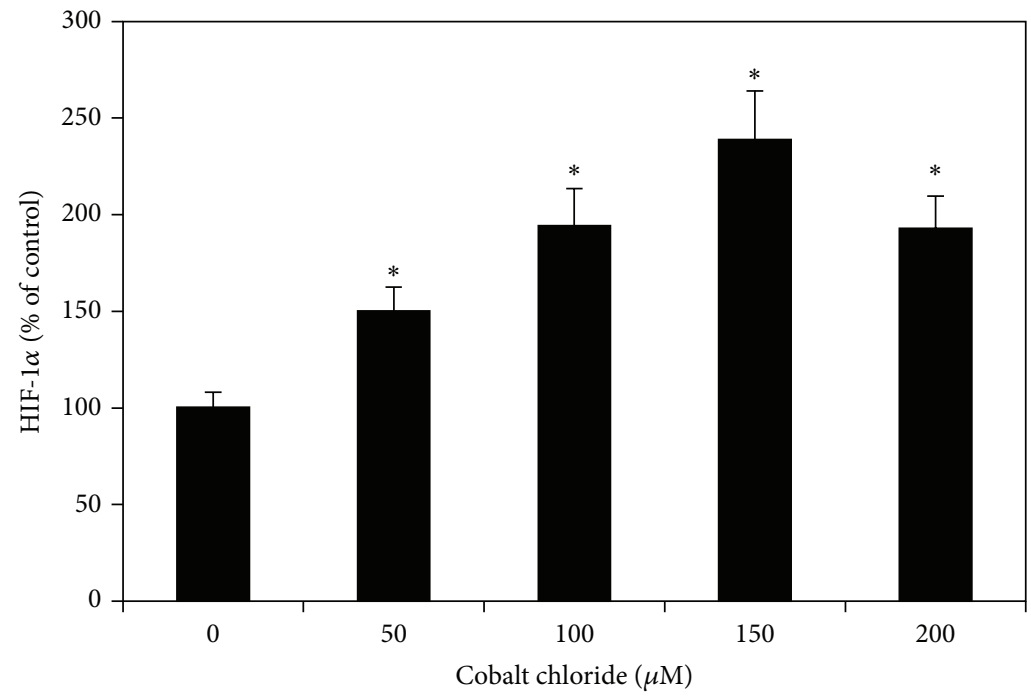

(b)

FiguRE 6: Effect of hypoxia on HIF-1 $\alpha$ protein levels in RPE cells. RPE cells were seeded into $6 \mathrm{~cm}$ culture dishes at a density of $2 \times 10^{6}$ cells per well. After $24 \mathrm{~h}$, cells were incubated in a controlled environment of $1 \% \mathrm{O}_{2}$ (a) or added with $\mathrm{CoCl}_{2}$ (b) at 50, 100, 150, and 200 $\mu \mathrm{M}$. Cells cultured under normoxic condition and without $\mathrm{CoCl}_{2}$ served as normal controls. Cells were collected $24 \mathrm{~h}$ later; HIF- $1 \alpha$ protein levels in cell extracts were determined by using the Intracellular HIF-1 $\alpha$ ELISA kits and expressed as percentages of the control (mean \pm SD, $n=3$ ). Hypoxia significantly increased HIF- $1 \alpha$ protein levels in RPE cells. ${ }^{*} P<0.05$, compared with the controls.

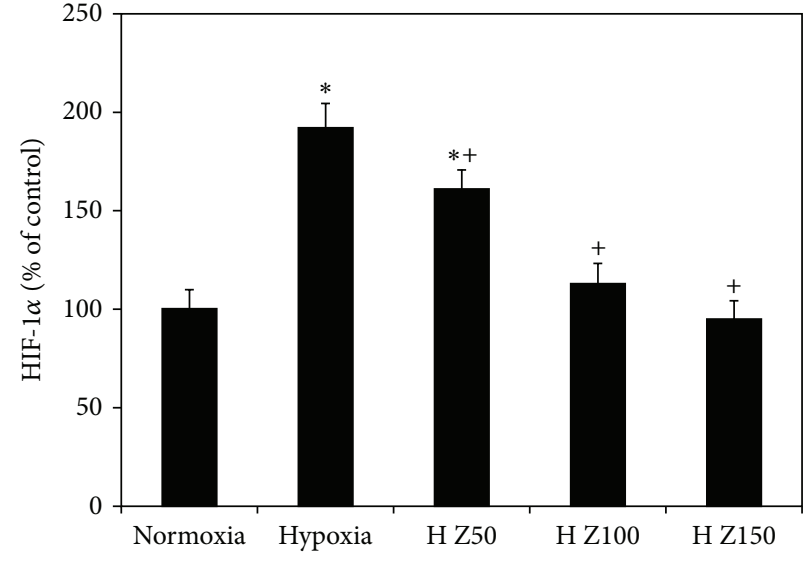

(a)

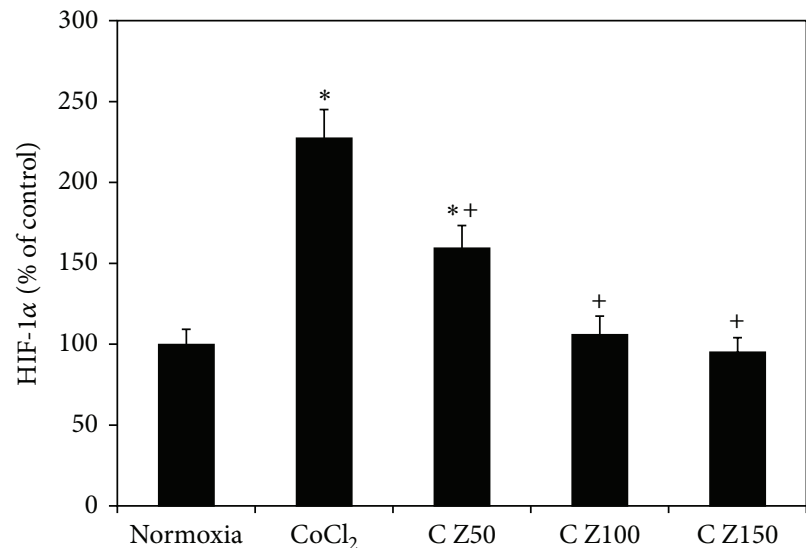

(b)

FIGURE 7: Effect of zeaxanthin on HIF-1 $\alpha$ protein levels in RPE cells under hypoxia. RPE cells were seeded into $6 \mathrm{~cm}$ culture dishes at a density of $2 \times 10^{6}$ cells per well. After $24 \mathrm{~h}$, zeaxanthin was added at 50, 100, and $150 \mu \mathrm{M}$ concentrations. One hour later, cells were incubated under $1 \% \mathrm{O}_{2}$ (a) or cultured with $\mathrm{CoCl}_{2}$ at $150 \mu \mathrm{M}$ (b). Cells cultured under normoxic condition and without zeaxanthin served as negative controls. Cells cultured under hypoxia and without zeaxanthin served as positive control. Cells were collected $24 \mathrm{~h}$ later; HIF-1 $\alpha$ protein levels in cell extracts were determined by using the Intracellular HIF-1 $\alpha$ ELISA kits and expressed as percentages of negative control (mean \pm SD, $n=3$ ). Zeaxanthin significantly inhibited hypoxia-induced accumulation of HIF- $1 \alpha$ protein. ${ }^{*} P<0.05$, compared with the negative controls. ${ }^{+} P<0.05$, compared with the positive controls.

deactivates the hydroxylases [59]. Therefore, cobalt is able to stabilize HIF-1 $\alpha$ protein and it has been used widely in experiments for producing chemical hypoxia [55-57, 60].

It has been reported that hypoxia-induced expression of VEGF mRNA and secretion of VEGF by RPE cells could be produced by culturing the cells under low oxygen environment (usually $1 \%$ oxygen) [10-16] or by adding $\mathrm{CoCl}_{2}$ $(100-200 \mu \mathrm{M})$ into the culture medium [55-57]. Hypoxia induces accumulation of HIF- $1 \alpha$ protein levels in RPE cells by culturing the cells in hypoxia [17-22] or by using $\mathrm{CoCl}_{2}$ $[55,60]$.

In the present study, hypoxia significantly induced expression of $V E G F$ and accumulation of HIF- $1 \alpha$ protein in cultured RPE cells. These results are consistent with the previous reports [10-22, 55-57].

Zeaxanthin is a carotenoid pigment and belongs to the xanthophyll subclass with a chemical formula $\mathrm{C}_{40} \mathrm{H}_{56} \mathrm{O}_{2}$. It is found at high levels in various foods (e.g., egg yolk, corn, 


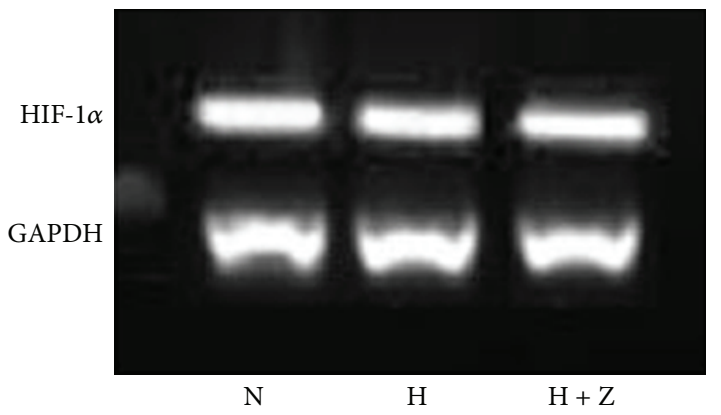

(a)

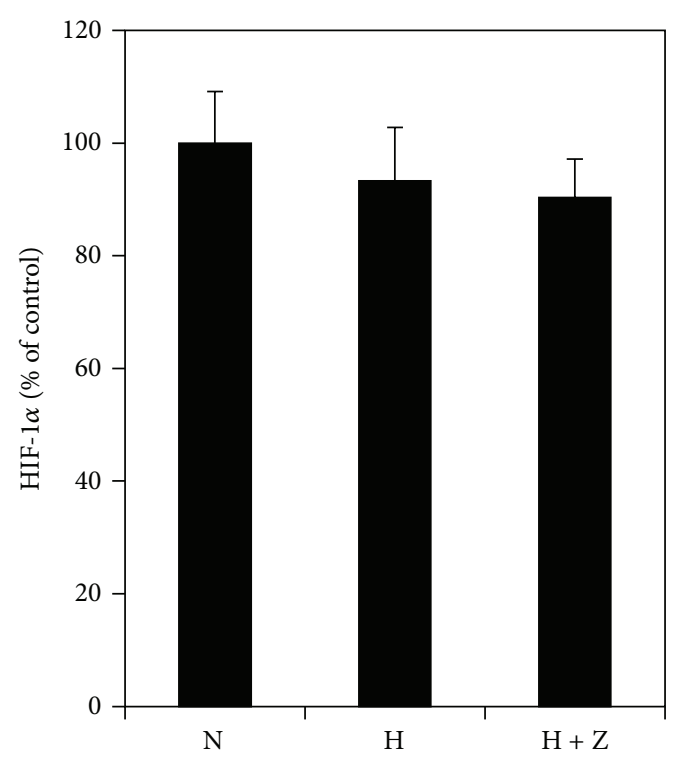

(b)

FIGURE 8: Effects of hypoxia and zeaxanthin on HIF-1 $\alpha$ mRNA expression of RPE cells. (a) Representative RT-PCR profiles from three experiments. Cells were cultured under hypoxia $(1 \%$ oxygen) with $(\mathrm{H}+\mathrm{Z})$ and without zeaxanthin $(\mathrm{H})$. Cells cultured under normal oxygen condition were used as the control $(\mathrm{N})$. Cells were collected 24 hours later, mRNA was extracted, and RT-PCR analysis was performed as described in Section 2. GAPDH was used as an internal loading control. (b) Quantitative analysis showed that the expression of HIF-1 $\alpha$ mRNA (mean $\pm \mathrm{SD}, n=3$ ) was not affected by being exposed to hypoxia or zeaxanthin $(P>0.05)$.

and many vegetables and fruits). Zeaxanthin is present in the tissues and is highly concentrated in the retina, especially in the macula [27-32].

Epidemiologic studies suggest that insufficient dietary lutein and zeaxanthin intake and lower levels of lutein and zeaxanthin in the retina or serum may be associated with increased risk for AMD [33-36]. Several but not all supplementation studies or clinical trials have shown that supplementation of zeaxanthin with other antioxidants may have a favorable effect on the prevention and treatment of AMD [37-40]. Recently, a meta-analysis study on 6 longitudinal cohort studies indicated that dietary intake of lutein and zeaxanthin was significantly related to a reduction of risk for late AMD but not for early AMD [41].

One in vitro study showed that zeaxanthin significantly reduced lipofuscin formation in photoreceptor outer segment-fed RPE cells [45]. Zeaxanthin reduces photooxidative damage and decreases upregulation of expression of IL8 (a proinflammation and angiogenic chemokine) in RPE cells caused by A2E and blue light irradiation [43]. Zeaxanthin protects cultured photoreceptors against oxidative stress caused by $\mathrm{H}_{2} \mathrm{O}_{2}$ or paraquat [46].

In an experimental animal study, zeaxanthin combined with other antioxidants increased retinal antioxidants activity and slowed down the photoreceptor degeneration in a retinitis pigmentosa model ( $\mathrm{rd} 1$ mouse) [61].

Zeaxanthin protects the retina against oxidative stresses by two mechanisms: it acts as an antioxidant or as a blue light filter [47]. In addition to these two traditional mechanisms, recent studies found that zeaxanthin and its closely related molecule (lutein) may affect the growth, viability, and functions of various cell types via different signal pathways, transcription factors, growth factors, and cytokines [46, 48].

Experimental animal studies showed that zeaxanthin could decrease the upregulation of VEGF in the retinalchoroid tissues in apolipoprotein deficient mice [50] and prevent diabetes-induced increase of retinal VEGF in diabetic rats [49]. Lutein has been reported to decrease high VEGF expression following tumor necrosis factor- $\alpha$ stimulation of human RPE cells and inhibits lipopolysaccharide-induced $V E G F$ expression in mouse macrophages [51]. A preliminary report suggested that adding oral zeaxanthin treatment $(20 \mathrm{mg} /$ day) to an aggressive treatment regimen (bevacizumab, steroid, and PDT therapy) for choroidal neovascularization $(\mathrm{CNV})$ improved therapeutic efficiency and reduced the number of PDT therapies. The progression to $\mathrm{CNV}$ in the fellow eye in zeaxanthin treated patients was reduced to $50 \%$ of patients without zeaxanthin [62]. However, the effects of zeaxanthin on VEGF expression in cultured RPE cells have not been previously reported.

In the present study, zeaxanthin did not cause a significant change in constitutive VEGF secretion by cultured human RPE cells. Zeaxanthin significantly reduced hypoxiainduced expression of VEGF mRNA and secretion of VEGF by RPE cells in a dose-dependent manner. Zeaxanthin at a higher concentration could completely block hypoxiainduced expression and secretion of VEGF by RPE cells. Zeaxanthin also inhibited hypoxia-induced intracellular accumulation of HIF-1 $\alpha$, which is the main transcription factor involved in hypoxia-induced expression of VEGF. 


\section{Conclusions}

In the present study, zeaxanthin blocked hypoxia-induced VEGF secretion in cultured RPE cells but not constitutive secretion of VEGF. Therefore, the possible detrimental effects caused by complete local blocking of VEGF might be avoided through the use of high-dose zeaxanthin supplementation [63-66]. Additionally, zeaxanthin, by inhibition of hypoxiainduced accumulation of HIF- $\alpha 1$ protein, may have a broader effect on the control of angiogenesis caused by factors other than VEGF $[26,67]$. Zeaxanthin taken orally could be used as an adjunct to intravitreal anti-VEGF therapy enabling a decrease in the frequency of injections with reduced risk of local side effects [68-70]. Therefore, zeaxanthin might be a promising agent to be explored for the prevention and treatment for a variety of retinal diseases associated with revascularization.

\section{Conflict of Interests}

The authors declare that there is no conflict of interests regarding the publication of this paper.

\section{Acknowledgments}

The authors thank Dr. Dennis L. Gierhart for his helpful comments and providing pure zeaxanthin. This work was supported by Bendheim Family Foundation, the Pathology Research Fund of New York Eye and Ear Infirmary, and an unrestricted grant from the Dennis L. Gierhart Charitable Gift Fund.

\section{References}

[1] R. M. B. Loureiro and P. A. D’Amore, "Transcriptional regulation of vascular endothelial growth factor in cancer," Cytokine \& Growth Factor Reviews, vol. 16, no. 1, pp. 77-89, 2005.

[2] K. Xie, D. Wei, Q. Shi, and S. Huang, "Constitutive and inducible expression and regulation of vascular endothelial growth factor," Cytokine and Growth Factor Reviews, vol. 15, no. 5, pp. 297-324, 2004.

[3] C. J. Pournaras, J. W. Miller, E. S. Gragoudas et al., "Systemic hyperoxia decreases vascular endothelial growth factor gene expression in ischemic primate retina," Archives of Ophthalmology, vol. 115, no. 12, pp. 1553-1558, 1997.

[4] A. N. Witmer, G. F. J. M. Vrensen, C. J. F. Van Noorden, and R. O. Schlingemann, "Vascular endothelial growth factors and angiogenesis in eye disease," Progress in Retinal and Eye Research, vol. 22, no. 1, pp. 1-29, 2003.

[5] O. Arjamaa, M. Nikinmaa, A. Salminen, and K. Kaarniranta, "Regulatory role of HIF- $1 \alpha$ in the pathogenesis of age-related macular degeneration (AMD)," Ageing Research Reviews, vol. 8, no. 4, pp. 349-358, 2009.

[6] J. S. Penn, A. Madan, R. B. Caldwell, M. Bartoli, R. W. Caldwell, and M. E. Hartnett, "Vascular endothelial growth factor in eye disease," Progress in Retinal and Eye Research, vol. 27, no. 4, pp. 331-371, 2008.

[7] J. W. Miller, A. P. Adamis, D. T. Shima et al., "Vascular endothelial growth factor/vascular permeability factor is temporally and spatially correlated with ocular angiogenesis in a primate model," The American Journal of Pathology, vol. 145, no. 3, pp. 574-584, 1994.

[8] N. Okamoto, T. Tobe, S. F. Hackett et al., "Transgenic mice with increased expression of vascular endothelial growth factor in the retina: a new model of intraretinal and subretinal neovascularization," The American Journal of Pathology, vol. 151, no. 1, pp. 281-291, 1997.

[9] I. A. Pierce, R. L. Avery, E. D. Foley, L. P. Aiello, and L. E. H. Smith, "Vascular endothelial growth factor/vascular permeability factor expression in a mouse model of retinal neovascularization," Proceedings of the National Academy of Sciences of the United States of America, vol. 92, no. 3, pp. 905-909, 1995.

[10] H. Wang, P. Geisen, E. S. Wittchen et al., "The role of RPE cellassociated $\mathrm{VEGF}_{189}$ in choroidal endothelial cell transmigration across the RPE," Investigative Ophthalmology and Visual Science, vol. 52, no. 1, pp. 570-578, 2011.

[11] C. F. Bento, R. Fernandes, P. Matafome, C. Sena, R. Seia, and P. Pereira, "Methylglyoxal-induced imbalance in the ratio of vascular endothelial growth factor to angiopoietin 2 secreted by retinal pigment epithelial cells leads to endothelial dysfunction," Experimental Physiology, vol. 95, no. 9, pp. 955-970, 2010.

[12] W.-C. Wu, Y.-H. Kao, P.-S. Hu, and J.-H. Chen, "Geldanamycin, a HSP90 inhibitor, attenuates the hypoxia-induced vascular endothelial growth factor expression in retinal pigment epithelium cells in vitro," Experimental Eye Research, vol. 85, no. 5, pp. 721-731, 2007.

[13] P. Geisen, J. R. McColm, B. M. King, and M. E. Hartnett, "Characterization of barrier properties and inducible VEGF expression of several types of retinal pigment epithelium in medium-term culture," Current Eye Research, vol. 31, no. 9, pp. 739-748, 2006.

[14] N. Ghiso, R. M. Rohan, S. Amano, R. Garland, and A. P. Adamis, "Suppression of hypoxia-associated vascular endothelial growth factor gene expression by nitric oxide via cGMP," Investigative Ophthalmology \& Visual Science, vol. 40, no. 6, pp. 1033-1039, 1999.

[15] H. G. T. Blaauwgeers, G. M. Holtkamp, H. Rutten et al., "Polarized vascular endothelial growth factor secretion by human retinal pigment epithelium and localization of vascular endothelial growth factor receptors on the inner choriocapillaris: evidence for a trophic paracrine relation," The American Journal of Pathology, vol. 155, no. 2, pp. 421-428, 1999.

[16] K. B. Cullberg, J. Olholm, S. K. Paulsen et al., "Resveratrol has inhibitory effects on the hypoxia-induced inflammation and angiogenesis in human adipose tissue in vitro," European Journal of Pharmaceutical Sciences, vol. 49, no. 2, pp. 251-257, 2013.

[17] F. Forooghian, R. Razavi, and L. Timms, "Hypoxia-inducible factor expression in human RPE cells," British Journal of Ophthalmology, vol. 91, no. 10, pp. 1406-1410, 2007.

[18] C. H. Lin, C. H. Li, P. L. Liao et al., "Silibinin inhibits VEGF secretion and age-related macular degeneration in a hypoxiadependent manner through the PI-3 kinase/Akt/mTOR pathway," British Journal of Pharmacology, vol. 168, no. 4, pp. 920 931, 2013

[19] P. Zhang, X. Zhang, X. Hao et al., "Racl activates HIF-1 in retinal pigment epithelium cells under hypoxia," Graefe's Archive for Clinical and Experimental Ophthalmology, vol. 247, no. 5, pp. 633-639, 2009.

[20] J. Zhu, Y.-S. Wang, J. Zhang et al., "Focal adhesion kinase signaling pathway participates in the formation of choroidal neovascularization and regulates the proliferation and migration of choroidal microvascular endothelial cells by acting through 
HIF-1 and VEGF expression in RPE cells," Experimental Eye Research, vol. 88, no. 5, pp. 910-918, 2009.

[21] Q. Xiao, S. Zeng, M. Lv, and S. Ling, "Small hairpin loop RNA targeting HIF- $1 \alpha$ down-regulates VEGF and up-regulates PEDF in human retinal pigment epithelial cells under hypoxic condition," Journal of Huazhong University of Science and Technology-Medical Science, vol. 28, no. 4, pp. 460-464, 2008.

[22] Q. Xiao, S. Zeng, S. Ling, and M. Lv, "Up-regulation of HIF$1 \alpha$ and VEGF expression by elevated glucose concentration and hypoxia in cultured human retinal pigment epithelial cells," Journal of Huazhong University of Science and Technology, vol. 26, no. 4, pp. 463-465, 2006.

[23] M.-C. Chen, C.-F. Lee, W.-H. Huang, and T.-C. Chou, "Magnolol suppresses hypoxia-induced angiogenesis via inhibition of HIF-1 $\alpha$ /VEGF signaling pathway in human bladder cancer cells," Biochemical Pharmacology, vol. 85, no. 9, pp. 1278-1287, 2013.

[24] H. Z. Imtiyaz and M. C. Simon, "Hypoxia-inducible factors as essential regulators of inflammation," Current Topics in Microbiology and Immunology, vol. 345, no. 1, pp. 105-120, 2010.

[25] M. C. Brihimi-Horn and J. Pouysségur, "HIF at a glance," Journal of Cell Science, vol. 122, no. 8, pp. 1055-1057, 2009.

[26] A. Weidemann and R. S. Johnson, "Biology of HIF-1 $\alpha$," Cell Death \& Differentiation, vol. 15, no. 4, pp. 621-627, 2008.

[27] O. Sommerburg, J. E. E. Keunen, A. C. Bird, and F. J. G. M. van Kuijk, "Fruits and vegetables that are sources for lutein and zeaxanthin: the macular pigment in human eyes," British Journal of Ophthalmology, vol. 82, no. 8, pp. 907-910, 1998.

[28] R. Vishwanathan, M. Neuringer, D. Max Snodderly, W. Schalch, and E. J. Johnson, "Macular lutein and zeaxanthin are related to brain lutein and zeaxanthin in primates," Nutritional Neuroscience, vol. 16, no. 1, pp. 21-29, 2013.

[29] E. J. Johnson, M. Neuringer, R. M. Russell, W. Schalch, and D. M. Snodderly, "Nutritional manipulation of primate retinas, III: effects of lutein or zeaxanthin supplementation on adipose tissue and retina of xanthophyll-free monkeys," Investigative Ophthalmology and Visual Science, vol. 46, no. 2, pp. 692-702, 2005.

[30] P. S. Bernstein, F. Khachik, L. S. Carvalho, G. J. Muir, D.-Y. Zhao, and N. B. Katz, "Identification and quantitation of carotenoids and their metabolites in the tissues of the human eye," Experimental Eye Research, vol. 72, no. 3, pp. 215-223, 2001.

[31] D. M. Snodderly, G. J. Handelman, and A. J. Adler, "Distribution of individual macular pigment carotenoids in central retina of macaque and squirrel monkeys," Investigative Ophthalmology \& Visual Science, vol. 32, no. 2, pp. 268-279, 1991.

[32] S. S. Ahmed, M. N. Lott, and D. M. Marcus, "The macular xanthophylls," Survey of Ophthalmology, vol. 50, no. 2, pp. 183193, 2005.

[33] J. M. Seddon, U. A. Ajani, R. D. Sperduto et al., "Dietary carotenoids, vitamins $\mathrm{A}, \mathrm{C}$, and $\mathrm{E}$, and advanced age-related macular degeneration," The Journal of the American Medical Association, vol. 272, no. 18, pp. 1413-1420, 1994.

[34] J. S. L. Tan, J. J. Wang, V. Flood, E. Rochtchina, W. Smith, and P. Mitchell, "Dietary antioxidants and the long-term incidence of age-related macular degeneration: the Blue Mountains Eye Study," Ophthalmology, vol. 115, no. 2, pp. 334-341, 2008.

[35] J. P. SanGiovanni, E. Y. Chew, T. E. Clemons et al., "The relationship of dietary carotenoid and vitamin $\mathrm{A}, \mathrm{E}$, and $\mathrm{C}$ intake with age-related macular degeneration in a case-control study: AREDS report No. 22," Archives of Ophthalmology, vol. 125, no. 9, pp. 1225-1232, 2007.
[36] T. Michikawa, S. Ishida, Y. Nishiwaki et al., "Serum antioxidants and age-related macular degeneration among older Japanese," Asia Pacific Journal of Clinical Nutrition, vol. 18, no. 1, pp. 1-7, 2009.

[37] S. Beatty, U. Chakravarthy, J. M. Nolan et al., "Secondary outcomes in a clinical trial of Carotenoids with Coantioxidants versus placebo in early age-related macular degeneration," Ophthalmology, vol. 120, no. 3, pp. 600-606, 2013.

[38] L. Ho, R. van Leeuwen, J. C. M. Witteman et al., "Reducing the genetic risk of age-related macular degeneration with dietary antioxidants, zinc, and $\omega-3$ fatty acids: the Rotterdam Study," Archives of Ophthalmology, vol. 129, no. 6, pp. 758-766, 2011.

[39] F. M. Barker II, "Dietary supplementation: effects on visual performance and occurrence of AMD and cataracts," Current Medical Research and Opinion, vol. 26, no. 8, pp. 2011-2023, 2010.

[40] The Age-Related Eye Disease Study 2 (AREDS2) Research Group, "Lutein + zeaxanthin and omega-3 fatty acids for agerelated macular degeneration: the Age-Related Eye Disease Study 2 (AREDS2) randomized clinical trial," The Journal of the American Medical Association, vol. 309, no. 19, pp. 2005-2015, 2013.

[41] L. Ma, H.-L. Dou, Y.-Q. Wu et al., "Lutein and zeaxanthin intake and the risk of age-related macular degeneration: a systematic review and meta-analysis," British Journal of Nutrition, vol. 107, no. 3, pp. 350-359, 2012.

[42] Q. Bian, S. Gao, J. Zhou et al., "Lutein and zeaxanthin supplementation reduces photooxidative damage and modulates the expression of inflammation-related genes in retinal pigment epithelial cells," Free Radical Biology and Medicine, vol. 53, no. 6, pp. 1298-1307, 2012.

[43] P. Bhosale, B. Serban, Y. Z. Da, and P. S. Bernstein, "Identification and metabolic transformations of carotenoids in ocular tissues of the Japanese quail Coturnix japonica," Biochemistry, vol. 46, no. 31, pp. 9050-9057, 2007.

[44] S. R. Kim, K. Nakanishi, Y. Itagaki, and J. R. Sparrow, "Photooxidation of A2-PE, a photoreceptor outer segment fluorophore, and protection by lutein and zeaxanthin," Experimental Eye Research, vol. 82, no. 5, pp. 828-839, 2006.

[45] S. E. G. Nilsson, S. P. Sundelin, U. Wihlmark, and U. T. Brunk, "Aging of cultured retinal pigment epithelial cells: oxidative reactions, lipofuscin formation and blue light damage," Documenta Ophthalmologica, vol. 106, no. 1, pp. 13-16, 2003.

[46] A. J. Chucair, N. P. Rotstein, J. P. SanGiovanni, A. During, E. Y. Chew, and L. E. Politi, "Lutein and zeaxanthin protect photoreceptors from apoptosis induced by oxidative stress: relation with docosahexaenoic acid," Investigative Ophthalmology and Visual Science, vol. 48, no. 11, pp. 5168-5177, 2007.

[47] E. Loane, J. M. Nolan, O. O’Donovan, P. Bhosale, P. S. Bernstein, and S. Beatty, "Transport and retinal capture of lutein and zeaxanthin with reference to age-related macular degeneration," Survey of Ophthalmology, vol. 53, no. 1, pp. 68-81, 2008.

[48] T. Tanaka, M. Shnimizu, and H. Moriwaki, "Cancer chemoprevention by carotenoids," Molecules, vol. 17, no. 3, pp. 3202-3242, 2012.

[49] R. A. Kowluru, B. Menon, and D. L. Gierhart, "Beneficial effect of zeaxanthin on retinal metabolic abnormalities in diabetic rats," Investigative Ophthalmology \& Visual Science, vol. 49, no. 4, pp. 1645-1651, 2008.

[50] P. Fernández-Robredo, S. Recalde, G. Arnáiz et al., "Effect of zeaxanthin and antioxidant supplementation on vascular 
endothelial growth factor (VEGF) expression in apolipoprotein-e deficient mice," Current Eye Research, vol. 34, no. 7, pp. 543-552, 2009.

[51] A. Kijlstra, Y. Tian, E. R. Kelly, and T. T. J. M. Berendschot, "Lutein: More than just a filter for blue light," Progress in Retinal and Eye Research, vol. 31, no. 4, pp. 303-315, 2012.

[52] D.-N. Hu, H. E. Savage, and J. E. Roberts, "Uveal melanocytes, ocular pigment epithelium, and Müller cells in culture: in vitro toxicology," International Journal of Toxicology, vol. 21, no. 6, pp. 465-472, 2002.

[53] W.-C. Wu, D.-N. Hu, H.-X. Gao et al., "Subtoxic levels hydrogen peroxide-induced production of interleukin- 6 by retinal pigment epithelial cells," Molecular Vision, vol. 16, pp. 1864-1873, 2010.

[54] D.-N. Hu, S. A. McCormick, R. Ritch, and K. Pelton-Henrion, "Studies of human uveal melanocytes in vitro: isolation, purification and cultivation of human uveal melanocytes," Investigative Ophthalmology \& Visual Science, vol. 34, no. 7, pp. 22102219, 1993.

[55] X. Dong, Y.-S. Wang, G.-R. Dou et al., "Influence of dll4 via hif- $1 \alpha$-vegf signaling on the angiogenesis of choroidal neovascularization under hypoxic conditions," PLoS ONE, vol. 6, no. 4, Article ID e18481, 2011.

[56] L. Notari, A. Miller, A. Martínez et al., "Pigment epitheliumderived factor is a substrate for matrix metalloproteinase type 2 and type 9: implications for downregulation in hypoxia," Investigative Ophthalmology and Visual Science, vol. 46, no. 8, pp. 2736-2747, 2005.

[57] B. Wang, Y. Zou, Z.-L. Yuan, and J.-G. Xiao, "Genistein suppressed upregulation of vascular endothelial growth factor expression by cobalt chloride and hypoxia in rabbit retinal pigment epithelium cells," Journal of Ocular Pharmacology and Therapeutics, vol. 19, no. 5, pp. 457-464, 2003.

[58] Z. Cui, E. Song, D.-N. Hu, M. Chen, R. Rosen, and S. A. McCormick, "Butein induces apoptosis in human uveal melanoma cells through mitochondrial apoptosis pathway," Current Eye Research, vol. 37, no. 8, pp. 730-739, 2012.

[59] Z. Zhang, J. Yan, Y. Chang, S. ShiDu Yan, and H. Shi, "Hypoxia inducible factor-1 as a target for neurodegenerative diseases," Current Medicinal Chemistry, vol. 18, no. 28, pp. 4335-4343, 2011.

[60] J.-H. Oh, A. Togloom, S.-W. Kim, and K. Huh, "Effects of ginkgo biloba extract on cultured human retinal pigment epithelial cells under chemical hypoxia," Current Eye Research, vol. 38, no. 10, pp. 1072-1082, 2013.

[61] M. M. Sanz, L. E. Johnson, S. Ahuja, P. A. R. Ekström, J. Romero, and T. van Veen, "Significant photoreceptor rescue by treatment with a combination of antioxidants in an animal model for retinal degeneration," Neuroscience, vol. 145, no. 3, pp. 1120-1129, 2007.

[62] R. J. Olk, E. Peralta, S. Sayegh, and D. L. Gierhart, "Does Oral zeaxanthin improve the anatomic and visual outcome of triple therapy for subfoveal choroidal $\mathrm{CNV}$ in age related macular degeneration (ARMD)," in Proceedings of the 44th Retina Society Meeting, Poster no. 17, Rome, Italy, 2011.

[63] K. Manousaridis and J. Talks, "Macular ischaemia: a contraindication for anti-VEGF treatment in retinal vascular disease?" British Journal of Ophthalmology, vol. 96, no. 2, pp. 179-184, 2012.

[64] Â. M. Carneiro, R. Costa, M. S. Falcão et al., "Vascular endothelial growth factor plasma levels before and after treatment of neovascular age-related macular degeneration with bevacizumab or ranibizumab," Acta Ophthalmologica, vol. 90, no. 1, pp. e25-e30, 2012.

[65] F. Semeraro, F. Morescalchi, F. Parmeggiani, B. Arcidiacono, and C. Costagliola, "Systemic adverse drug reactions secondary to anti-VEGF intravitreal injection in patients with neovascular age-related macular degeneration," Current Vascular Pharmacology, vol. 9, no. 5, pp. 629-646, 2011.

[66] J. Christoforidis, R. Ricketts, C. Pratt et al., "The effect of intravitreal anti-VEGF agents on peripheral wound healing in a rabbit model," Clinical Ophthalmology, vol. 6, no. 1, pp. 61-69, 2012.

[67] H. R. Rezvani, N. Ali, L. J. Nissen et al., "HIF-1 $\alpha$ in epidermis: oxygen sensing, cutaneous angiogenesis, cancer, and noncancer disorders," Journal of Investigative Dermatology, vol. 131, no. 9, pp. 1793-1805, 2011.

[68] R. Nuzzi and F. Tridico, "Local and systemic complications after intravitreal administration of anti-vascular endothelial growth factor agents in the treatment of different ocular diseases: a fiveyear retrospective study," Seminars in Ophthalmology, 2013.

[69] S. Day, K. Acquah, P. Mruthyunjaya, D. S. Grossman, P. P. Lee, and F. A. Sloan, "Ocular complications after antivascular endothelial growth factor therapy in medicare patients with age-related macular degeneration," The American Journal of Ophthalmology, vol. 152, no. 2, pp. 266-272, 2011.

[70] D. Y. Choi, M. C. Ortube, C. A. McCannel et al., "Sustained elevated intraocular pressures after intravitreal injection of bevacizumab, ranibizumab, and pegaptanib," Retina, vol. 31, no. 6, pp. 1028-1035, 2011. 


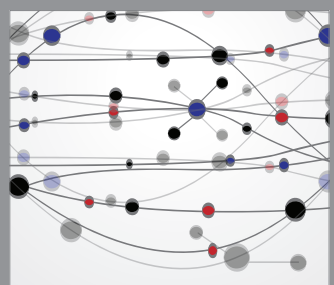

The Scientific World Journal
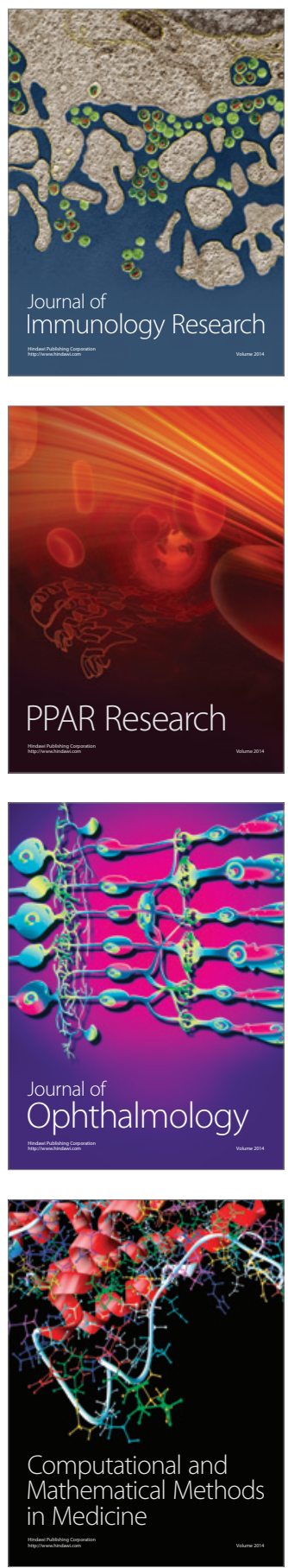

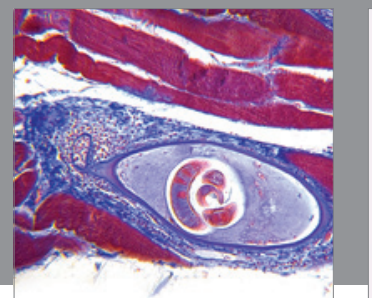

Gastroenterology

Research and Practice
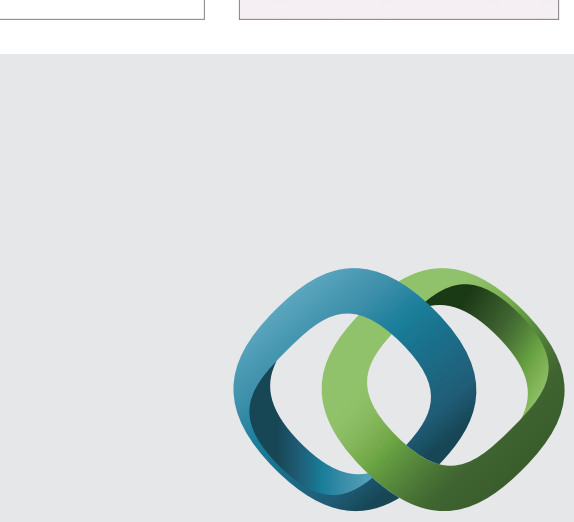

\section{Hindawi}

Submit your manuscripts at

http://www.hindawi.com
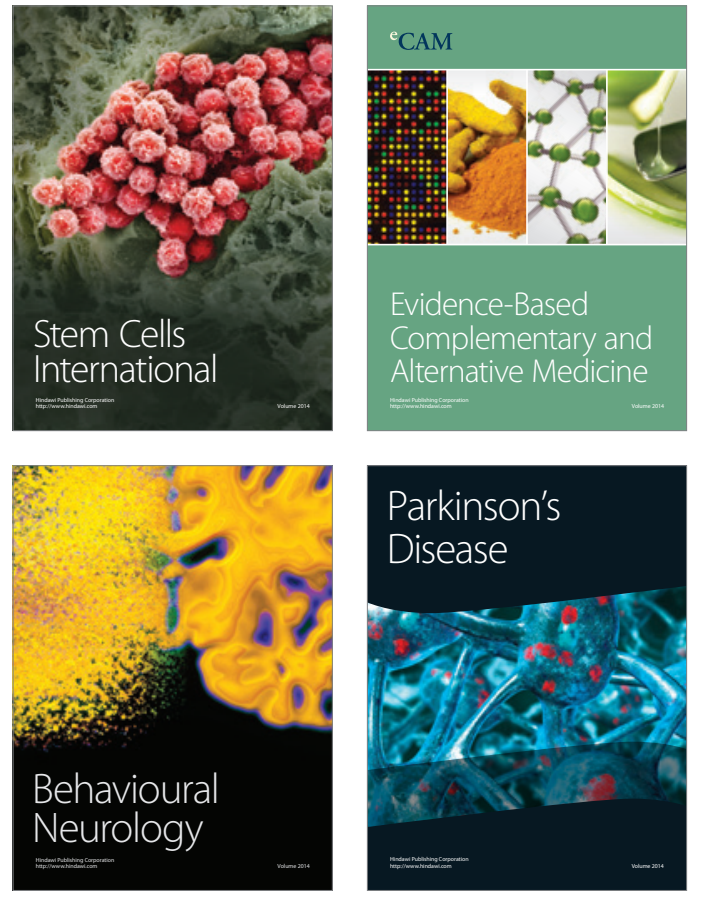
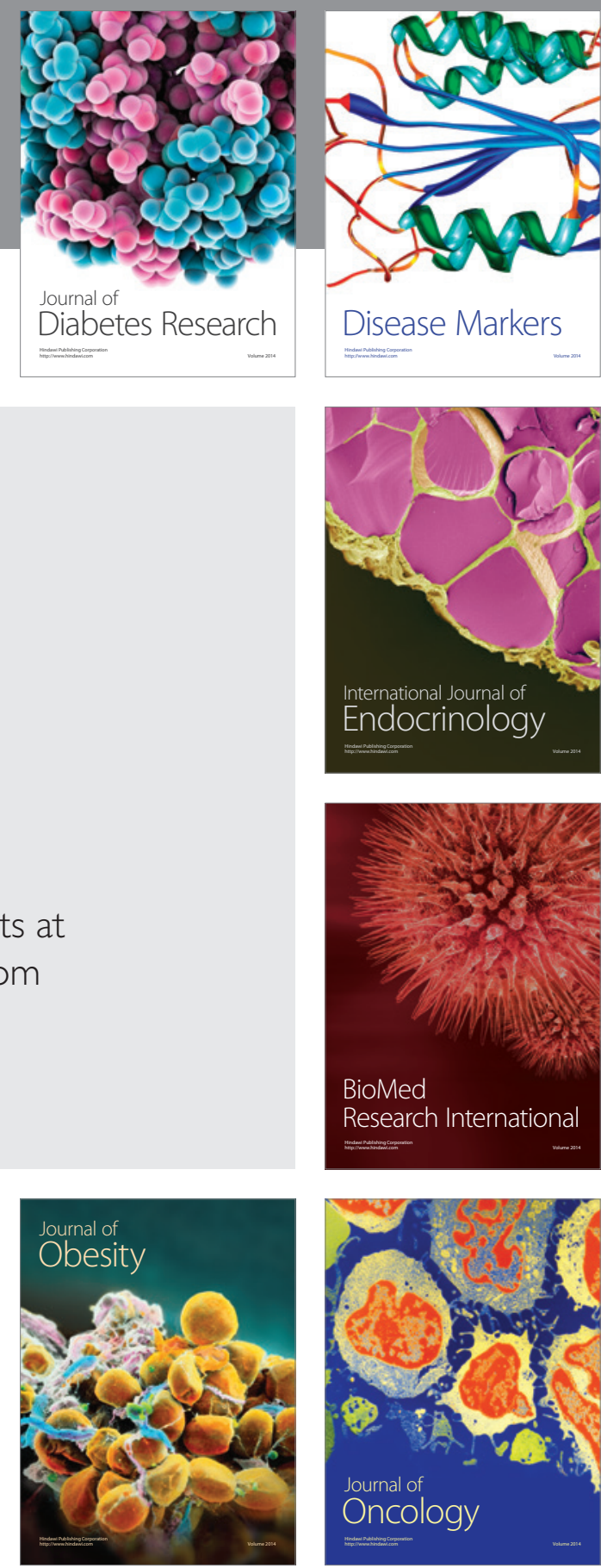

Disease Markers
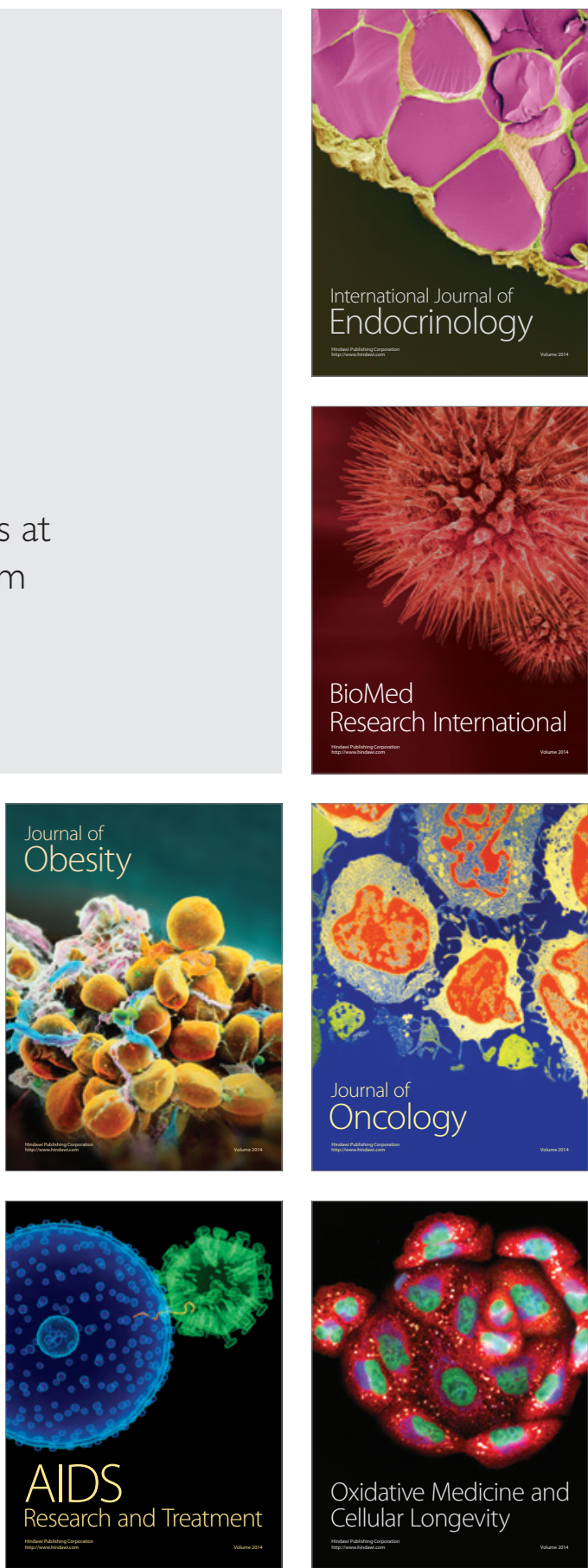